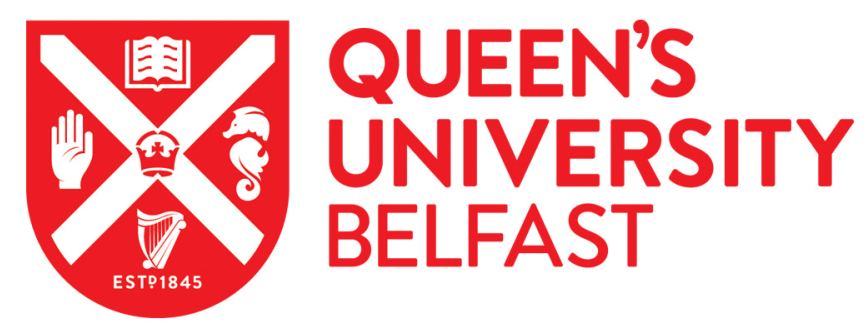

\title{
The European Convention in Conflicted Societies: The Experience of Northern Ireland and Turkey
}

Bakircioglu, O., \& Dickson, B. (2017). The European Convention in Conflicted Societies: The Experience of Northern Ireland and Turkey. International and Comparative Law Quarterly, 66(2), 263-294.

https://doi.org/10.1017/S0020589317000033

Published in:

International and Comparative Law Quarterly

Document Version:

Peer reviewed version

Queen's University Belfast - Research Portal:

Link to publication record in Queen's University Belfast Research Portal

Publisher rights

Copyright 2017 British Institute of International and Comparative Law.

This work is made available online in accordance with the publisher's policies. Please refer to any applicable terms of use of the publisher.

\section{General rights}

Copyright for the publications made accessible via the Queen's University Belfast Research Portal is retained by the author(s) and / or other copyright owners and it is a condition of accessing these publications that users recognise and abide by the legal requirements associated with these rights.

Take down policy

The Research Portal is Queen's institutional repository that provides access to Queen's research output. Every effort has been made to ensure that content in the Research Portal does not infringe any person's rights, or applicable UK laws. If you discover content in the Research Portal that you believe breaches copyright or violates any law, please contact openaccess@qub.ac.uk. 


\section{The European Convention in Conflicted Societies: The Experience of Northern Ireland and Turkey}

\section{Dr Onder Bakircioglu and Prof Brice Dickson ${ }^{1}$}

\section{Introduction}

During the 63-year life of the European Convention to date, Europe has witnessed an array of conflicts. This article reviews the role played by the Convention in two of them - the conflict in Northern Ireland between those who want it to remain part of the United Kingdom and those who want it to become part of a re-unified Ireland, and the conflict in Turkey between State authorities and the armed supporters of an independent or autonomous Kurdish region where Kurds could enjoy greater political and cultural rights. The main aim is to assess the principles and procedures which the Convention organs in Strasbourg have developed in response to applications lodged by victims of human rights abuses alleged to have been committed during these two conflicts. The assessment will reveal whether Strasbourg has succeeded in adopting an approach which can contribute to a reduction in human rights abuses and to a speedier solution of conflicts. The findings may be relevant when the European Court of Human Rights and the Committee of Ministers are confronted by other serious conflicts, such as in the Balkans or the Caucasus.

It was in 1969 that serious civil unrest broke out in Northern Ireland. Seeds of serious Kurdish unrest were sown in Turkey in 1978 and a large uprising occurred in 1984. In each of the two States the conflict revolved around claims to territory and the rights of ethnopolitical minorities. In Northern Ireland a substantial minority of the population (up to $40 \%$ at times, mainly Catholics) wanted the area to be part of Ireland rather than part of the United Kingdom, while in Turkey a substantial minority (up to 20\%) claimed that their Kurdish identity was not being appropriately recognized under Turkish law. In response to the unrest both the UK and Turkish governments adopted special security measures, including some new laws, and it was mainly these which resulted in numerous applications being lodged in Strasbourg. The challenge facing the Commission and Court was to ensure that victims of human rights abuses had access to justice but also that governments should

\footnotetext{
${ }^{1}$ Respectively, Senior Lecturer in Law at the University of Leicester (ob51@leicester.ac.uk) and Professor of Law at Queen's University Belfast (b.dickson@qub.ac.uk). The authors acknowledge the benefit of discussions during early thinking about this article with Dr Darren Dinsmore, Lecturer in Law at the University of Kent, but the views expressed in this version are entirely their own.
} 
have some margin of appreciation to take measures which they deemed proportionate to deal with the unrest. No doubt the Commission and Court wanted the conflicts to be resolved, but their primary goal was to see that in particular cases a fair decision was reached as to whether human rights had been abused or not. Although the conflicts did occasionally spill over into neighbouring States, they were essentially internal security threats and not conflicts between nations. They each involved violent insurgencies, led in Northern Ireland by the Irish Republican Army (the IRA), although other paramilitary organizations were active as well, and in Turkey by the Kurdistan Workers Party (the PKK). Some assistance was provided to the insurgents by external sources - money from the USA and arms from Libya in the case of the IRA, money, logistical support and weapons from Syria, Iran and Northern Iraq in the case of the PKK. Between 1969 and 1998 (when the Belfast (Good Friday) Agreement was reached) more than 3,600 people were killed in Northern Ireland. Since 1984, when the insurgency grew in intensity, more than 45,000 people have been killed in Turkey.

Having each joined the Council of Europe in 1949, the United Kingdom and Turkey were amongst the first countries to ratify the European Convention on Human Rights. The United Kingdom became bound by it in 1953 and Turkey in 1954. The United Kingdom accepted the jurisdiction of the European Court in inter-State cases as soon as it was established in 1959, and granted individuals the right to petition the European Commission of Human Rights in 1966. Turkey granted the right of individual petition to the European Commission in 1987 but did not accept the jurisdiction of the European Court until 1990. Prior to 1987 only inter-state cases brought against Turkey could be considered in Strasbourg, and then only by the Commission. The conflict in Northern Ireland was at the heart of the first ever decision reached by the European Court in $1960^{2}$ and was also the focal point of the first inter-State case to result in a judgment from the European Court in 1978. ${ }^{3}$ Turkey faced an inter-State complaint from France, Norway, Denmark, Sweden and the Netherlands concerning alleged human rights abuses committed by the military government in the early 1980s, but this was settled before reaching the Court, ${ }^{4}$ as was another inter-State case taken by Denmark against Turkey relating to the alleged illtreatment of a Danish national while detained in Turkey. ${ }^{5}$ When Turkey was eventually

\footnotetext{
${ }^{2}$ Lawless v Ireland (1979-80) 1 EHRR 1.

${ }^{3}$ Ireland v UK (1979-80) 2 EHRR 25.

${ }^{4}$ (1983) 35 DR 143.

${ }^{5}$ (2000) 29 EHRR CD35.
} 
brought before the European Court by another State, it was in relation to its actions in Cyprus. ${ }^{6}$

As will be explained below, applications relating to the conflicts in Northern Ireland and Turkey have led the Court to elaborate new substantive doctrines, especially in relation to the right to life and the right not to be ill-treated, as well as new procedural approaches, especially in relation to exhaustion of domestic remedies and fact-finding. Much, though, still remains to be done to make the European Convention a more effective instrument in conflict resolution. The fact that the Convention is notoriously weak on the protection of minorities is a significant encumbrance in this regard. ${ }^{7}$ Another salient feature of the Court's approach has been its reluctance to find a government responsible for systematic abuses of human rights during counter-insurgency activities. Its focus on individual cases appears to make the Court loathe to issue more general pronouncements about a State's overall response to civil unrest.

This article proceeds by summarising the main features of Strasbourg's engagement with the conflict in Northern Ireland before turning to how it has engaged with the conflict in Turkey. The latter section cross-refers to the former where appropriate and the article concludes with some brief general conclusions regarding the ability of the ECHR to play a significant role during times of serious non-international conflicts.

\section{The Conflict in Northern Ireland}

The number of applications lodged with the European Commission and Court of Human Rights arising out of the conflict in Northern Ireland is much less than that arising out of the conflict in Turkey. ${ }^{8}$ In general terms, the Strasbourg organs have moved over time from a relatively 'hands-off' approach to a much more interventionist one. This is partly attributable to better presentation of applications by applicants' lawyers but also to a growing maturity within the European Court itself as it has gradually developed a method for ensuring that human rights are not easily sacrificed on the altar of political expediency within Member States. As will be seen, Strasbourg's more 'hands-on' approach to cases stemming from the conflict in Turkey is partly a consequence of the relative severity of the human rights violations committed by the security forces there: while security forces

\footnotetext{
${ }^{6}$ Cyprus v Turkey (2002) 35 EHRR 30.

${ }^{7}$ Though see the more upbeat account given by Geoff Gilbert, 'The burgeoning minority rights jurisprudence of the European Court of Human Rights' (2002) $24 H R Q 736$.

${ }^{8}$ For a comprehensive survey see Brice Dickson, The European Convention on Human Rights and the Conflict in Northern Ireland (Oxford: Oxford University Press; 2010).
} 
often behaved badly in Northern Ireland, the outrages were by no means as frequent nor as premeditated as in Turkey. They were also subjected to much greater scrutiny by domestic courts and independent reviewers. Moreover the abuses in Northern Ireland were committed at a time when international law placed less emphasis on the rights of individuals and more on the interests of States. ${ }^{9}$

\section{Initial applications under the Convention}

Initial applications to Strasbourg focused on claims of religious discrimination in the way public housing was being allocated by local councils in Northern Ireland, with some Protestant-controlled councils tending to favour Protestant applicants. They also raised complaints about the 'gerrymandering' of electoral areas, whereby constituencies with a majority of Catholic voters elected fewer representatives than comparably-sized constituencies with a majority of Protestant voters. In addition, complaints were made about the draconian nature of some of the Regulations issued under the Civil Authorities (Special Powers) Acts (NI) 1922-44. Because the United Kingdom did not recognize the right of individual petition until 1966, the only hope of getting Strasbourg's attention on these issues before then was by bringing an inter-State case, but the Irish government refused to initiate such a case, despite being lobbied to do so by several prominent nationalists in Ireland, North and South.

Six applications were eventually lodged by individuals in 1968, and a further seven in 1969. But all of these came to nothing, mainly because the lawyers helping with the cases did not fully co-operate with the bodies in Strasbourg, and the European Commission eventually struck the cases out of the list. ${ }^{10}$ An application lodged by a member of the UK Parliament, Bernadette Devlin, was declared inadmissible too. ${ }^{11}$ At her trial for inciting people to commit riotous behavior she had wanted to call witness evidence to show that she was only trying to prevent illegal actions by the police, but the Commission sheltered behind the nostrum that national authorities have a wide discretion as to what evidence is or is not admissible at a trial. A further set of applications was lodged in Strasbourg in

\footnotetext{
${ }^{9}$ This point is confirmed by the Appeals Chamber of the International Court for the Former Yugoslavia in Tadic, where it was held that such traditional distinctions as those between international and non-international armed conflicts gradually lose weight in terms of basic human rights violations, largely because international law is no longer exclusively concerned with safeguarding State interests. In the court's language, 'a Statesovereignty-oriented approach has been gradually supplanted by a human-being-oriented approach.' Prosecutor v Dusko Tadic, No: IT-94-1, ICTY, 2 October 1995, paras. 96-97.

${ }^{10}$ (1970) Ybk 340, 434. A chronology of the proceedings and exchange of correspondence is set out at 358-386.

1137 CD 146 (3 February 1971); (1971) Ybk 634.
} 
1971 and 1972, raising, amongst other points, the retrospective legitimation by the Northern Ireland Act 1972 of illegal actions by British soldiers (allegedly in breach of ECHR Article 7) and the interference by British authorities in the correspondence between complainants and their lawyer. ${ }^{12}$ The former were dismissed on the basis that the applicants were non-victims (which also put an end to complaints about the Special Powers Acts and the overall conduct of the security forces in Northern Ireland); the latter failed for lack of evidence.

Early applications to Strasbourg from Northern Ireland seem to have foundered because they were not carefully enough formulated and managed. Given the youthfulness of the institutions applied to, there was, understandably, a degree of uncertainty as to what would or would not pass muster in Strasbourg, but, looking back, one might still have hoped that convincing claims by deserving applicants could have been made out. Boyle, Hadden and Hillyard, writing in 1974, go some way towards explaining why the domestic legal system of Northern Ireland was failing the people who lived there, ${ }^{13}$ but they might also have stressed the lack of knowledge about the European Convention at that time.

Subsequent applications were more successful, but by no means in every respect. We will consider them under the headings of the right to liberty, the right not to be illtreated, the right to life and the right to a fair trial.

\section{The right to liberty}

In 1971 the use of internment without trial was authorised in Northern Ireland. Hundreds of men who were sympathetic to the cause of Irish republicanism were detained without trial, some for what turned out to be more than three years. The system did not end until 1975. ${ }^{14}$ The same practice had been employed in the Republic of Ireland during an earlier bout of troubles (1956-62) and in the European Court's first ever decision, Lawless $v$ Ireland,${ }^{15}$ the Court upheld the validity of the practice because Ireland had lawfully derogated from its obligations under Article 5 due to the 'public emergency threatening the life of the nation.' For the first time the Court held that during grave public

\footnotetext{
${ }^{12} M M v U K$ and $X, Y$ and $Z v U K$ App Nos 5155/71, 5727/72, 5744/72, 5857/72, 6 DR 13 (1976) and 14 DR 5 (1978). $X v U K$ App No 5459/72, 40 CD 7 (1972) dealt with the alleged interference with correspondence.

${ }^{13}$ Kevin Boyle, Tom Hadden and Paddy Hillyard, Law and State: The Case of Northern Ireland (London: Martin Robertson; 1974) ch 2.

${ }^{14}$ For details see G Hogan and C Walker, Political Violence and the Law in Ireland (1989) 86-100.

15 (1979-80) 1 EHRR 1. See, generally, Brian Doolan, Lawless v Ireland (1957-1961): The First Case

Before the European Court of Human Rights (Aldershot: Ashgate Publishing; 2001).
} 
emergencies 'Contracting States would have a certain margin of appreciation'. ${ }^{16}$ This doctrine has occupied a crucial position within the Strasbourg jurisprudence ever since and was a crucial barrier to more effective scrutiny by the Court of measures taken in both Northern Ireland and Turkey to counter the insurgencies in those jurisdictions. ${ }^{17}$

Ironically, it was the introduction of internment in Northern Ireland that finally persuaded the Irish government ${ }^{18}$ to raise an inter-State challenge against the United Kingdom in Strasbourg in 1971. ${ }^{19}$ In 1972 the European Commission declared the bulk of the allegations admissible ${ }^{20}$ but in 1976 , more than four years after the application was lodged, the Commission unanimously decided that the measures for detention without trial, in derogation from Article 5 of the Convention were, indeed 'strictly required by the exigencies of the situation' under Article 15(1). ${ }^{21}$ Although the internment tactic targeted only Republicans (and not 'Loyalists') the Commission also rejected the argument that the way in which internment had been operated violated Article 14 of the Convention, read in conjunction with Article 5. The decision confirmed the broad measure of discretion States enjoyed in derogation cases. This case also provided the opportunity for Strasbourg organs to clarify the rationale for the margin of appreciation doctrine. It was stressed that 'by reason of their direct and continuous contact with the pressing needs of the moment,' national authorities are better placed to decide whether to derogate from a right in public emergency situations, ${ }^{22}$ even when the disputed security measures clearly discriminated between competing unlawful paramilitary groups. Ireland $v U K$ signaled the wide extent to which State-centered arguments were preferred in public emergency cases as a consequence of the Strasbourg organs significantly self-limiting their powers of review.

The inter-State case was referred to the European Court of Human Rights in 1976, but almost two more years were to elapse before it issued its judgment. ${ }^{23}$ During those two years there were 409 conflict-related deaths in Northern Ireland, 2,989 bombs were

\footnotetext{
${ }^{16}$ Lawless v Ireland, App No 332/57, 2 Ybk 318 (1960), paras 28-30.

${ }^{17}$ See, Oren Gross and Fionnuala Ní Aoláin, 'From discretion to scrutiny: revisiting the application of the margin of appreciation doctrine in the context of Article 15 of the European Convention on Human Rights' (2002) 23 HRQ 625; Onder Bakircioglu, 'The application of the margin of appreciation doctrine in freedom of expression and public morality cases,' (2007) 8 German LJ 711.

18 The details of this decision-making process are described by William Schabas and Aisling O'Sullivan in 'Of politics and poor weather: how Ireland decided to sue the United Kingdom under the European Convention on Human Rights' in (2007) 2 Irish Ybk of Int' L 3.

${ }^{19}$ App No 5310171 (1971) 14 Ybk 100.

20 (1972) 15 Ybk 76.

${ }^{21}$ (1976) 19 Ybk 512; publications of the European Court of Human Rights, Series B: Pleadings, Oral Arguments and Documents, Vol 23-1(1980).

22 Ireland v UK, App No 5310/71 (18 January, 1978), para 207.

23 (1979-80) 2 EHRR 25.
} 
planted, 1,427 weapons and 19.6 tons of explosives were found, and 2,584 persons were charged with terrorist offences. In 1978 the European Court confirmed the view of the Commission that the use of internment in Northern Ireland was not a violation of the Convention, just as it had held more than 16 years earlier that internment in the Republic of Ireland during the 1950s was also permissible. The Court said that the United Kingdom had validly derogated from the application of Articles 5 and 6, simply asserting that the existence of the public emergency was 'perfectly clear from the facts'. ${ }^{24}$

Viewed retrospectively, it is rather remarkable that at a time when a wide variety of politicians and academics in Britain and Ireland were commenting on the counterproductiveness of internment in Northern Ireland, and when other European countries facing serious terrorist attacks (such as West Germany and Italy) were not finding it necessary to resort to internment, the European Court should - with so little detailed analysis - condone the practice. The last internee had been released even before the European Commission adopted its report into the Irish government's application, so it was not as if a finding by the European Court against the United Kingdom's use of internment would have driven a coach and horses through current national policy and practice in relation to the control of terrorism in Northern Ireland. As we will see, the Court did hold that the United Kingdom had breached Article 3, which makes it all the more difficult to understand why there was no adverse finding in relation to Article 5 too. It is also disappointing that the European Court did not deal in any detail with the serious allegations made against the UK government to the effect that it had failed to properly cooperate with the European Commission and Court in their consideration of the Irish government's allegations.

When indefinite internment ended in 1975 the UK government relied instead on 'executive detention', whereby an arrested suspect could be held by the police for up to 48 hours and then detained purely on the order of a government minister for a further five days before having to be either charged and brought before a judge for a decision on the lawfulness of the detention or released without charge. ${ }^{25}$ The application in Brogan $v U K^{26}$ was the prompt for the European Court to issue a ruling that, in general, no-one can be held in detention without being brought before a judicial authority for more than 96 hours. In practice, however, this decision made little difference because the United Kingdom

\footnotetext{
24 (1979-80) 2 EHRR 25, 91, para 25.

${ }^{25}$ Prevention of Terrorism (Temporary Provisions) Act 1974, s 7(2), later replaced by a comparable provision in 1976, 1984 and 1989; it was not repealed until the Terrorism Act 2000 came into force in February 2001. ${ }^{26}$ (1989) 11 EHRR 117. See too O'Hara v UK (2002) 34 EHRR 812.
} 
reacted by re-introducing the derogation from Article 5 which it had inexplicably withdrawn four years earlier, in 1984. When the new derogation was later challenged, the Court had little hesitation in upholding its validity. ${ }^{27}$ It was even upheld in a case relating to an arrest in 1998, four years after the IRA's first ceasefire in 1994 (which was broken in 1996 but renewed in 1997). ${ }^{28}$ It is clear that after 1975 in Northern Ireland short-term internment in effect replaced indefinite internment.

The European Court did insist that arrest powers in Northern Ireland should be founded on reasonable suspicion, not just suspicion, ${ }^{29}$ but the domestic law had already been changed by the time that judgment was issued and one can question whether the change made any real difference in practice. Certainly Strasbourg has not been very strong as regards the right of arrested people to be told the grounds of their arrest: in Brogan $v$ $U K^{30}$ the Court held that reasonable suspicion of involvement in 'terrorism' was enough (without mention having to be made of any specific offences) and in Kerr $v U K^{31}$ it held that the applicant detainee should have been able to work out for himself, from the questions put to him over the course of 39 interviews within a week, why he had been arrested. The record on delays in trials and on the availability of bail is better: in the early case of Orchin $v U K^{32}$ the Commission found a breach of Article 6 where the applicant had been remanded on bail for no less than four years before being tried in relation to the possession of firearms, and in Gault $v U K^{33}$ (a non-troubles related case) the Court found a breach of Article 5 where a woman had been refused bail pending her re-trial for aiding and abetting the murder of her husband. In McKay $v U K,{ }^{34}$ however, the Grand Chamber held that there was no breach of Article 5(3) when an alleged armed robber was brought before a magistrate who was empowered to consider the lawfulness of his arrest but not whether he should be granted bail.

The Convention proved of little use in controlling the operation of powers to detain people for long periods at ports and airports, ${ }^{35}$ or to exclude them from discrete parts of the United Kingdom.

\footnotetext{
${ }^{27}$ Brannigan and McBride (1993) 17 EHRR 539.

${ }^{28}$ Marshall $v$ UK App No 41571/98, decision of 19 July 2001.

${ }^{29}$ Fox, Campbell and Hartley v UK (1991) 13 EHRR 157. Contrast Murray (Margaret) v UK (1994) I9 EHRR 193.

${ }^{30}$ See, n 26 above.

31 (2000) 29 EHRR CD 184.

32 (1984) 6 EHRR 391.

${ }^{33}$ (2008) 46 EHRR 48.

34 (2007) 44 EHRR 41.

${ }^{35}$ McVeigh, O'Neill and Evans v UK (1983) 5 EHRR 71.
} 


\section{The right not to be ill-treated}

The first case to raise issues concerning the alleged mistreatment of detainees in Northern Ireland was Donnelly $v U K .^{36}$ There were seven applicants involved, this time carefully selected on the basis of their actual victimhood. Each of the men alleged that he had been beaten while in police custody - some said that they had received blows to the head and body, others that they had been kicked in the genitals or given electric shocks to their genitals. Three of the applicants even alleged that against their will they had been administered 'truth drugs' to make them confess to crimes. In all they referred to 157 specific cases of alleged ill-treatment. ${ }^{37}$ The applicants asked for a temporary injunction to put a halt to such practices pending the outcome of their applications. They also asked for their applications to be given expedited consideration and for a full investigation to be conducted into the alleged systemic brutality. With commendable speed, the European Commission announced just seven weeks after the applications had been lodged that it would indeed expedite their consideration but that it had no power to issue a temporary injunction. $^{38}$

In 1973, the Commission declared the applications to be admissible, ${ }^{39}$ which in itself was a significant triumph for the applicants, not only because the Commission was prepared to proceed with the case even though similar allegations were still pending before the European Commission in the inter-State application lodged by Ireland in 1971, ${ }^{40}$ but also because it established two propositions which have since become firm rules within the European Convention system. The first is that an individual can complain that an administrative practice is a systematic breach of the Convention provided that he or she adduces prima facie evidence of such a practice and of the applicant being a victim of it. ${ }^{41}$ The second is that when an individual alleges the existence of such an administrative practice he or she does not first have to exhaust domestic remedies in that regard: instead, the question of the effectiveness of those domestic remedies can be considered at the same time as, and as part of, the merits of the application. ${ }^{42}$ These were remarkably progressive

\footnotetext{
36 (1973) Ybk 212, 43 CD 122 (admissibility); (1975) 4 DR 4 (merits).

37 (1973) Ybk 212, 216.

38 (1973) Ybk 212; 43 CD 122.

${ }^{39}$ Ibid.

40 The Commission decided to allow the overlapping allegations to be considered because under Art 27(1)(b) of the Convention an application is to be excluded from consideration if it is substantially the same as a matter which has 'already been examined', and the inter-State case had not yet been examined. 4143 CD 122, 146.

42 The Commission quoted what it had said in the First Greek Case, App No 3321-3/67; (1969) 12bis
} 
conclusions for the time and marked a somewhat unheralded coming-of-age for the European Commission in its handling of applications under the Convention. This article will show below that allegations of an administrative practice and exceptions to the rule of prior exhaustion of domestic remedies also came to characterize a sizeable portion of security-related applications lodged from Turkey.

Unfortunately, the initial triumph at the admissibility stage in Donnelly $v$ UK turned out to be a Pyrrhic victory. After the Commission had examined the merits of the claim, it decided that the alleged administrative practice could not be considered to be in violation of the Convention because evidence had not been adduced to show that it rendered domestic remedies ineffective or inadequate. ${ }^{43}$ Three of the seven applicants were held not to have exhausted the local remedies available to them within the legal system of Northern Ireland. The other four had already received financial settlements in respect of their claims. The Commission was therefore of the view that it had been shown that the machinery for providing compensation had worked effectively in practice. It considered at some length the applicants' wider argument that, in the circumstances prevailing in Northern Ireland, compensation was not an adequate remedy for their complaints, since they were allegedly the victims of an administrative practice, ${ }^{44}$ but it concluded that the procedures in place to prevent the occurrence or repetition of the acts complained of were effective enough for the purposes of the Convention.

All in all, the Donnelly case presented a further lesson to applicants and lawyers alike. Providing that a State is systematically failing to comply with its Convention obligations is extremely difficult, especially at a time when a conflict is raging and the collection of hard evidence is highly problematic. The reluctance of the Strasbourg organs to implicate the government in systematic violations of human rights persisted in insurgency-related Turkish cases as well. Suggestions that a State is failing in its obligations can be easily defeated by the State showing that it is making its best effort to prevent abuses of rights. In the 1970s and 1980s, moreover, it was almost always fatal to an applicant's case that he or she had started civil legal proceedings in the domestic legal system, for this automatically undermined any allegations that domestic remedies were ineffective, even in Article 3 cases.

\footnotetext{
Ybk at 194.

43 (1975) 4 DR 4.

${ }^{44}$ Ibid, 77-85.
} 
Allegations concerning the ill-treatment of detainees were also dealt with during the inter-State case of Ireland $v U K$ referred to above. In particular the Irish government alleged that detainees were being hooded, spread-eagled for long periods against walls, deprived of food, water and sleep, and exposed to continuous loud or monotonous noises during their custody. The UK government, obviously disturbed by these applications, announced that the use of the impugned interrogation techniques had been stopped; at the same time the Prime Minister stated that 'interrogation in depth' would continue. ${ }^{45}$ In its report on the merits of the applications, issued in $1976,{ }^{46}$ the Commission unanimously found that the techniques employed during the detaining and interrogating of suspects amounted to 'torture. ${ }^{47}$ This was less than two months after the Commission's decision in Donnelly $v$ $U K$, where it had rejected the allegation that there was an administrative practice to mistreat detainees and that there were no effective domestic remedies available to address complaints of mistreatment. When the Court, in its first occasion to pronounce on an interState matter, reviewed the Commission's decision in $1978,{ }^{48}$ it was asked not to consider individual cases but whether the United Kingdom was engaging in a State practice in breach of Article 3. All of the 14 individuals involved had already received compensation of between $£ 10,000$ and $£ 25,000$ from UK authorities for the treatment they had endured. By 13 votes to four the Court held that these five techniques did not amount to torture. Instead, by 16 votes to one, it held that they were inhuman and degrading treatment, on the ground that the drafters clearly intended to reserve the label of torture for actions which were particularly cruel and caused intense suffering. The one judge who thought that the use of the five techniques did not even amount to degrading treatment was Sir Gerald Fitzmaurice, the UK judge, and amongst the four judges who agreed with the European Commission that what had happened in Northern Ireland was torture was the Irish judge, Philip O'Donoghue. ${ }^{49}$ On the issue of whether the UK government had properly co-operated with the Commission's investigations of the alleged incidents, the European Court 'regretted'

\footnotetext{
${ }^{45}$ Statement of 2 March 1972 (see, Ireland v UK (1979-80) 2 EHRR 25, para 153). The world was to learn in 2011, in the report of the Baha Mousa Inquiry, that in fact the use of these techniques had not been abandoned by the British army. Some of them were still being employed by UK forces in Iraq in 2003: www.bahamousainquiry.org, Vol 2, Parts IV to IX.

${ }^{46}$ Published in 1976-78 ECHR, Ser B, vol 23-1, 377-90; extracts appeared in (1976) 19 Ybk 512.

${ }^{47}$ See, M O'Boyle, 'Torture and Emergency Powers under the European Convention on Human Rights:

Ireland v United Kingdom' (1977) 71 Am J Int'l L 674.

48 (1979-80) 2 EHRR 25.

${ }^{49} \mathrm{He}$ was the Irish member of the European Commission from 1965 to 171 and was the Irish judge on the Court from 1971 to 1980. When appointed to the Commission he was 69, so when he retired from the Court he was 84. He had been called to the Bar before the partition of Ireland, in 1919, and was made State Counsel in 1939.
} 
the Government's attitude. ${ }^{50}$ Just recently it has come to light that even within the British government the five techniques were described as torture, ${ }^{51}$ so those of the so-called 'hooded men' who are still alive are now seeking to have the case re-opened within Northern Ireland so that a further investigation can take place into whether the government deliberately misled the Strasbourg authorities. ${ }^{52}$ The Irish government has also asked the European Court to revise its 1978 judgment in the light of the revelations about the British government's apparent duplicity. ${ }^{53}$

Boyle observes that ' $[\mathrm{t}]$ he real significance of the findings in Ireland $v U K$ was the emphasis placed by the Commission and Court on the inadequacy of remedies during the period it was examining'. ${ }^{54}$ It may be speculated that if such interrogation methods were to be practised today, the Court might have reached a different conclusion, probably with the same rationale that underpinned its decision. Certainly, over the decades the Court's attitude has somewhat shifted in this area, which is not surprising given its preference for interpreting the Convention as a 'living instrument', to be developed in light of changing circumstances. ${ }^{55}$ Such a change in the Court's attitude regarding torture was made clear in Selmouni v France ${ }^{56}$ where the Court, finding the French State responsible for violating Article 3 of the Convention, noted that:

certain acts which were classified in the past as 'inhuman and degrading treatment' as opposed to 'torture' could be classified differently in future...[T]he increasingly high standard being required in the area of the protection of human rights and fundamental liberties

\footnotetext{
${ }^{50}$ In the words of Brian Simpson: 'The British declined to identify either the locations where they had been. used or the senior individual who authorized their use. The British did not produce Brigadier Kitson, the military officer in command in Belfast at the time, as a witness. Witnesses who were produced were instructed to answer no questions about the practice of interrogation. Plainly, there was something deeply embarrassing to conceal, though the squalid details of what was done were already public knowledge. One can only speculate as to what else had to be concealed.' ('Round up the usual suspects: the legacy of British colonialism and the European Convention on Human Rights' (1995-96) 41 Loy L Rev 629, 707.) Simpson concludes this long article by saying that 'the United Kingdom's record of failure under the European Convention, with the high point reached in Ireland $v$ United Kingdom, can only be regarded as lamentable' (708).

${ }^{51}$ See www.thejournal.ie/rte-documentary-torture-1498698-Jun2014/, last accessed 4 April 2016.

${ }^{52}$ Leave to bring judicial review proceedings was granted on 4 June 2015: see www.bbc.co.uk/news/uknorthern-ireland-33008186, last accessed 4 April 2016.

${ }^{53} \mathrm{See}$ www.theguardian.com/world/2014/dec/02/ireland-european-court-hooded-men, last accessed 4 April 2016.

54 'Human rights and political resolution in Northern Ireland' (1982-83) 9 Yale J World Pub Ord 156, 1667.

55 Tyrer $v$ UK (1978-80) 2 EHRR 1, para 31.

56 (2000) 29 EHRR 403.
} 
correspondingly and inevitably requires greater firmness in assessing breaches of the fundamental values of democratic societies. ${ }^{57}$

Given that the European Court is never totally free from the political context within which it is operating, it is understandable that the Court exercised extreme caution while dealing with a highly sensitive, politically charged case where, as Ní Aoláin pointed out, 'a leading Western democracy [was] being accused of [using] systematic torture in the context of a fraught internal conflict in Northern Ireland to which the British government had committed its military forces'. ${ }^{58}$ As will be seen in the context of the Turkish cases, while the Court did take some daring decisions holding the State responsible for torture, in the majority of cases the high threshold set to distinguish torture from inhuman and degrading treatment has rigorously been applied to absolve the State from the stigma of torture.

\section{The right to life}

Allegations that the British security forces had breached the right to life of protestors and terrorist suspects were also raised by the Irish government in the inter-State case, but were held to be inadmissible for lack of evidence. Other cases raising the same right had either also been declared inadmissible (because, for example, there was evidence that the victim was rioting at the time, ${ }^{59}$ or that the security forces had acted in self-defence ${ }^{60}$ ) or had been settled. ${ }^{61}$ Complaints about the killing of 14 people by British soldiers in Derry on 30 January 1972 ('Bloody Sunday') were dismissed for being out of time, having not been lodged until 1994. ${ }^{62}$ But a breakthrough occurred when the European Court held in McCann $v$ UK, by 10 votes to nine, that when undercover British soldiers shot dead three members of the IRA in Gibraltar in 1988, believing that they were about to detonate a car bomb, Article 2 had been violated, because the operation to arrest the bombers had not been carefully enough planned. ${ }^{63}$ This case reaffirmed the principle that the use of lethal force must be strictly necessary for, and proportionate to, the achievement of the law enforcement

\footnotetext{
${ }^{57}$ Ibid, para 101.

${ }^{58}$ Fionnuala Ní Aoláin, 'The European Convention on Human Rights and its Prohition on Torture,' in Sanford Levinson, Torture: A Collection (Oxford: Oxford University Press; 2004) 213, 216.

${ }^{59}$ Stewart v UK (1985) 7 EHRR CD453.

${ }^{60}$ Kelly v UK (1993) 74 DR 139.

${ }^{61}$ Farrell v UK (1983) 5 EHRR 465. See, too, Caraher v UK (2000) 29 EHRR CD119, where the European Court rejected an argument that the UK was operating an administrative practice of 'buying off' the families of victims shot by security forces by offering them compensation.

${ }^{62}$ McDaid v UK (1996) 22 EHRR CD197.

${ }^{63}$ For an account of how this duty to plan carefully has been subsequently developed by the European Court see Dickson, (Strasbourg, 2016).
} 
objective. ${ }^{64}$ The decision emphasized States' positive obligations to take effective security measures before resorting to the use of lethal force and to conduct effective official investigation into suspicious deaths. This meant that States were not merely to refrain from taking life unless absolutely necessary for one of the purposes set out in Article 2(2), but that when death transpires they must take positive measures to investigate the circumstances and provide appropriate remedies in case of any fault attributable to the security forces. These principles have since been applied in numerous other cases, including applications taken against Turkey, where the absence of effective official inquiries into arbitrary deprivation of the right to life (or of property) were often found to constitute breaches of the Convention. ${ }^{65}$

In a series of decisions issued in cases from Northern Ireland on 4 May 2001, ${ }^{66}$ the European Court developed a set of procedural obligations which have to be met by States when investigating deaths. As a result, amongst the current requirements of an Article 2 compliant investigation are that it be independent of those alleged to have caused the loss of life, that it be initiated by the State rather than by the victim's family or friends, that it be prompt and thorough, that it be capable of identifying whether excessive force was used and who might have been responsible for using it, and that it keep the next-of-kin of the deceased informed about the progress of the investigation. The system for holding inquests in Northern Ireland was found to be in breach of additional requirements in that persons who caused the death were not required to give evidence at the inquest, the deceased 's nextof-kin could not get legal aid to attend, and the coroner and jury could not produce findings which would play an effective role in securing anyone's prosecution.

There have been several subsequent decisions by the European Court on applications brought from Northern Ireland in which the Court has held that the requirements for a proper investigation have not been met. ${ }^{67}$ In fact the UK government is still under scrutiny by the Committee of Ministers for not having fully implemented the judgments issued in May 2001. As discussed below, the authorities in Turkey have also been required to meet the exacting investigatory standards laid down by Strasbourg bodies, which demand the identification and potential punishment of those responsible for human

\footnotetext{
${ }^{64}$ McCann v UK (1996) 21 EHRR 97, para 149.

65 See, e.g., Akdivar v Turkey (1996) 23 EHRR 143.

${ }^{66}$ Jordan v UK (2003) 37 EHRR 2; Kelly v UK App No 30054/96; McKerr v UK (2002) 34 EHRR 20; Shanaghan $v$ UK App No 37715/97.

${ }^{67}$ See, McShane v UK (2002) 35 EHRR 23; Finucane v UK (2003) 37 EHRR 29; Brecknell v UK (2008) 46 EHIRR 42; Hemsworth v UK, App No 58559/09, judgment of 16 July 2013.
} 
rights abuses and the provision of compensation for the damages sustained by victims. ${ }^{68}$ However, unlike in the Turkish cases, no relative of a deceased person in Northern Ireland has ever been found to have had his or her Article 3 rights breached while waiting for the proper investigation of a killing, though they have received damages for breach of their Article 2 rights in that context. ${ }^{69}$ Likewise, the European Court has never ruled that State security forces in Northern Ireland violated the negative duty not to take life in Northern Ireland.

\section{The right to a fair trial}

The United Kingdom set up special juryless courts in Northern Ireland ('Diplock courts') to try people accused of 'scheduled offences', but these were never condemned by the Strasbourg Court as being in breach of Article 6 of the Convention. In some ways they may have operated more fairly than jury trials, since the judges in question were obliged to give written treasons for their conclusions and persons convicted had an automatic right of appeal to a three-judge Court of Appeal. Likewise, attempts to limit the right of accused persons to remain silent during police questioning were very largely held to be consistent with that provision in Murray (John) $v U K .{ }^{70}$ Later, though, the lack of access to a solicitor, when coupled with the limits on the right to remain silent, was found to be a violation, ${ }^{71}$ and in another case the conditions in which a detainee was held were found to tip the scale in favour of there being a breach. ${ }^{72}$ These conditions had been experienced by hundreds of former detainees but had never previously been condemned in such terms by either a domestic or an international court.

In the absence of any imaginative use of Article 14 in the Northern Ireland context, it was Article 6 which eventually came to the aid of people who were unable to challenge alleged discrimination at their workplace on the basis of their religious belief or political opinion. In Tinnelly \& Son Ltd and McElduff $v U K^{73}$ the Court found that this was a denial of access to justice. This decision was announced three months after the Belfast (Good

\footnotetext{
${ }^{68}$ See, e.g., Menteş v Turkey (1998) 26 EHRR 595; Selcuk and Asker v Turkey (1998) 26 EHRR 477.

${ }^{69}$ E.g. Hemsworth $v$ UK, n 67 above, where the Court awarded the wife and father of a deceased man $€ 20,000$ in compensation under Art 2. Damages have also been awarded for investigative delay in domestic courts: see, e.g., Re Jordan's Applications [2015] NICA 66, where £7,500 was a warded in compensation for delays caused by the Police Service of Northern Ireland during the inquest into a killing.

70 (1996) 22 EHRR 29.

${ }^{71}$ Averill v UK (2000) 31 EHRR 839.

${ }^{72}$ Magee v UK, ibid.

73 (1999) 27 EHRR 249. See too Devenney v UK (2002) 35 EHRR 643 and Devlin v UK (2002) 34 EHRR 1029 , where $£ 10,000$ was awarded for loss of opportunity in each case.
} 
Friday) Agreement in 1998 and the UK authorities found that thereafter they could easily dispense with the previous practice whereby a government Minister was able to issue a certificate preventing someone from receiving a fair hearing of his or her complaint of discrimination. A comparable volte-face occurred in 2000 when the head of the police in Northern Ireland announced that solicitors were henceforth to be allowed to sit with detainees when they were being interviewed by the police. The head of the police and the government had previously argued that there was no legislative authority for such a practice, yet in the end it was able to be adopted without any new law or regulation having to be passed. ${ }^{74}$

\section{The Conflict in Turkey}

The armed conflict between the Kurdish insurgents (PKK) and the Turkish military has claimed more than 45,000 lives and injured countless more since 1984. Following Turkey's recognition of the right of individual petition in 1987, an unprecedented series of conflict-related applications have been received by the Strasbourg organs, ${ }^{75}$ which seized an exceptional opportunity to craft novel principles concerning counterinsurgency practices. The resulting decisions and judgments not only brought to light the grave breaches of human rights, but also compelled Turkey to revisit some of its security policies.

It is generally recognized that Turkey's poor human rights record in general, and the unresolved Kurdish question in particular have been among the main reasons why Turkey's candidacy to join the EU has faltered. It was first lodged in 1987 but the candidacy was not officially recognized by the European Council until the summit held in Helsinki in 1999. While candidate status for EU membership has acted as a spur for Turkey to undertake some major human rights reforms, and even to enter into, presently mired, peace talks with the PKK, the 'Kurdish question' is still far from being resolved. Since first coming to power in 2002 (it won its fifth consecutive electoral victory in November 2015) the ruling Justice and Development Party (AKP) has certainly altered the economic and political landscape of Turkey (particularly during its first two terms of office up to 2011) and thus somewhat improved the country's long-lamented human rights record.

\footnotetext{
${ }^{74}$ For further details see Dickson, $n 8$ above, 182-4.

${ }^{75}$ By the end of 2015, the ECtHR had delivered 3,182 judgments concerning Turkey, of which 2,812 found at least one violation of the Convention. This places Turkey at the apex of the ECtHR's condemnation profile, the next worst state being Italy, with 2,336 judgments of which 1,781 found at least one violation.. See 'Violations by Article and by State, 1959-2015', available on the website of the ECtHR at www.echr.coe.int/Documents/Stats_violation_1959_2015_ENG.pdf, last accessed 22 April 2016.
} 
Nonetheless, human rights issues connected with the Kurdish question remain centre-stage amid the uncertainty over frustrated attempts at bringing about a durable peace settlement.

The following section will focus on Strasbourg's approach to the anti-terrorism measures adopted by the Turkish state in response to the PKK insurgency. As with Northern Ireland critical issues will be explored, such as the exhaustion and effectiveness of domestic remedies, the declaration of states of emergency and resort to derogations, and the allegations of discrimination and systematic administrative malpractices, with a view to shedding a brighter light on the actual and potential impact of the European Convention on conflicted societies.

\section{The right to individual petition}

The troubled situation in southeast Turkey led the authorities to introduce a long lasting emergency regime (from 1987 to 2002), which instigated serious restrictions on basic freedoms, including of assembly, association, speech and movement. According to a 1997 Turkish Parliamentary Report, over 500 hundred conflict-related applications were lodged at Strasbourg about such incidents as village destructions, forceful disappearances, extrajudicial killings and torture. ${ }^{76}$

The chief reason for the Kurdish applicants to invoke the Strasbourg machinery was the general disinclination of the Turkish regional courts to exercise effective jurisdiction. Kurdish applicants, who were aided by prominent Irish and British lawyers such as Kevin Boyle (who was experienced in handling conflict-related cases from Northern Ireland) and Françoise Hampson, engaged in strategic litigation at Strasbourg to try to bring about concrete changes in domestic law and practice as well as increase awareness of the 'Kurdish reality. ${ }^{77}$ The applications proved largely successful in drawing attention not only to the controversial anti-terrorism measures in Turkey but to the general weakness of the domestic remedies in providing some form of redress. The precedent-setting case of Akdivar, ${ }^{78}$ which calls to mind the position adopted by the ECmHR in the Northern Irish case of Donnelly in $1973,{ }^{79}$ introduced an exception to the rule of exhaustion of local remedies. In assessing

\footnotetext{
${ }^{76}$ Report of the Turkish Parliamentary Scrutiny Committee Established for Studying and Determining Necessary Measures for the Problems of Citizens Who Emigrated Because of Village Evacuations in the East and Southeast, (10/25), 1997, No 532, p 1.

${ }^{77}$ See, Dilek Kurban et al, 'Supranational Rights Litigation, Implementation and the Domestic Impact of Strasbourg Court Jurisprudence: A Case Study of Turkey’, Project Report Funded by the European Commission, 2008, pp 4-10.

${ }^{78}$ Akdivar, n 65 above.

${ }^{79}$ See the text at n 36 et seq above.
} 
whether domestic remedies had to be exhausted at all times, the Court held that account had to be taken not only of the formal remedies at hand, but of the particular circumstances of each case. The Court concluded that there was no requirement to exhaust domestic remedies if those remedies were inadequate. It added, however, that 'its ruling [was] confined to the particular circumstances of the present case. ${ }^{80}$ In other words, the relaxation of the exhaustion rule did mean that there was an automatic entitlement to circumvent local remedies. The Court maintained its traditional approach in other cases, where it stressed that its position on nonexhaustion of local remedies was not to be interpreted as a general statement that remedies were ineffective in southeast Turkey or that future applicants were absolved from the obligation to have initial recourse to domestic courts. ${ }^{81}$

During the admissibility hearings the Turkish government displayed considerable suspicion towards the applicants who were complaining about counter-insurgency measures. ${ }^{82}$ The government also accused petitioners of manipulating the Convention system in order to undermine Turkey's national security and legitimate the activities of the PKK. ${ }^{83} \mathrm{It}$ further maintained that the failure of applicants to exhaust local remedies was an abuse of the right of individual petition and part of a strategy aimed at denigrating Turkey. ${ }^{84}$ In response to such claims, the ECtHR stated that the respondent State's arguments could be accepted only if it were clear that the applications were based on untrue facts, which here had not been demonstrated. ${ }^{85}$

Another issue faced by the applicants concerned the right to petition under Article 25 of the ECHR without any hindrance from the State (now Article 34). Some applicants complained that they were subjected to pressure from the authorities to modify or withdraw their applications. In Akdivar, where the applicants were questioned by domestic authorities about their petitions, the Court found a violation of Article $25 .{ }^{86}$ In $K u r t,{ }^{87}$ the Court held that the government's pressure on the applicant to withdraw her application was illicit, and that the threat of criminal measures against her lawyer was unacceptable. ${ }^{88}$ In Orhan, ${ }^{89}$ where the

\footnotetext{
${ }^{80} \mathrm{~N} 65$ above, paras 70 and 77.

${ }^{81}$ Aksoy v Turkey (1996) 23 EHRR 553, para 53; Menteş n 56 above, para 61.

82 Salih Orhan v Turkey (1997) Commission Admissibility Decision, App No 25656/94.

${ }^{83}$ Akdivar, Cicek, Aktas and Karabulut v Turkey (1994) Commission Admissiblity Decision, App No

21893/93; also see, Cagirca v Turkey (1994) Commission Admissiblity Decision, App No 21895/93.

${ }^{84}$ Akdivar, n 65 above, paras 51-55.

${ }^{85}$ Mizgin Ovat v Turkey, (1995) Commission Admissiblity Decision, App No 23180/94; Akdivar, n 65 above, para 54.

${ }^{86}$ Akdivar, n 65 above, paras 105-106.

${ }^{87}$ Kurt v Turkey (1998) ECHR 44.

${ }^{88}$ Ibid, paras 153-165

${ }^{89}$ Orhan v Turkey App No 25656/02, judgment of 18 June 2002.
} 
applicant was summoned before the prosecutor on account of his application, the ECtHR similarly found this direct contact with the applicant to be inappropriate. In analogous cases, the Court consistently stated that Member States had to avoid dissuading or discouraging applicants or their representatives from pursuing a Convention remedy..$^{90}$

\section{First instance fact-finding}

In view of persistent strong disagreements between applicants and the Turkish government over the depiction of alleged events stemming from the emergency region, the Convention organs deemed it necessary to hold fact-finding hearings in order to adjudicate on important factual inconsistencies. These hearings proved particularly vital not only in cases where there were marked discrepancies between the claims, but also where local authorities seemed to have avoided disclosing key evidence. Although fact-finding was meant to be exceptional, it became such a common practice that Turkish cases ${ }^{91}$ constitute 66 per cent of all the fact-finding missions conducted in the history of the Convention system. ${ }^{92}$ In the inter-State case relating to Northern Ireland very extensive fact-finding hearings took place as well: the seriousness of the conflict meant that some of these could not take place in Northern Ireland itself, or even in London, and so they were held in Norway. ${ }^{93}$

In the cases examined by the Convention organs the authorities' most frequently occurring failures relate to the lack of on-site investigations, the scarcity of witness testimony referring to critical issues, exclusive reliance on official statements on those issues, denial of fair trial guarantees, deficiencies or distortions in custody records and a lack of effective local remedies. ${ }^{94}$ While fact-finding exercises revealed that certain violations had been repeatedly committed, ${ }^{95}$ the Court chose to treat each case on its individual merits. ${ }^{96}$ Nonetheless, factfinding hearings ${ }^{97}$ were generally successful in undercutting official denials of any wrongdoing

\footnotetext{
${ }^{90}$ See Tanrikulu v Turkey (2000) 30 EHRR 950, paras 126-133; Aksoy, n 81 above, paras 101-106.

${ }^{91}$ See, e.g., Aksoy, n 81 above; Aktas v Turkey (2003) 38 EHRR 18; Aydin v Turkey (1997) 25 EHRR 251.

${ }^{92}$ See, Philip Leach et al, International Human Rights \& Fact Finding: An Analysis of the Fact-Finding Missions Conducted by the European Commission and Court of Human Rights, Report by the Human Rights and Social Justice Research Institute at London Metropolitan University, 2009, p 26.

93 The European Commission delegated a group of its members to hear the testimony of no fewer than 119 witnesses put forward by the Irish and UK governments; this took a period of 30 days. In addition there were 11 days of oral submissions made to the Commission by the two governments.

${ }^{94}$ See Kaya v Turkey (1999) 28 EHRR 1, at pp 324-6 of Report; Ergi v Turkey (2001) 32 EHRR 18, at pp 17781779 of Report; Cakiçi v Turkey (2001) 31 EHRR 5; Aydin n 91 above; Tanrikulu n 90 above. See also Basak Cali, 'The Logics of Supranational Human Rights Litigation, Official Acknowledgement, and Human Rights Reform: The Southeast Turkey Cases before the European Court of Human Rights, 1996-2006' (2010) 35 Law \& Social Inquiry 325.

${ }_{95}$ Ipek $v$ Turkey (2004) ECHR 74, para 137.

${ }^{96}$ Orhan, n 89 above, paras 393-394.

${ }^{97}$ Strasbourg organs came to refrain from fact-finding hearings after the end of 1990s, when the conflict lost its
} 
in the emergency region, which in turn undermined the official claim that applicants had acted with the main motive of discrediting the State.

\section{Allegations of systematic violations}

As in Northern Ireland, Turkish cases in Strasbourg emerged against a backdrop of an entrenched political crisis which engendered acts of terrorism, but also unconventional counter-terrorism measures that violated human rights on a large scale. Allegations of an 'administrative practice' featured regularly in the individual applications during the $1990 \mathrm{~s},{ }^{98}$ where it was essentially argued that the violations suffered amounted to a systematic practice due to their unremitting and discriminatory character and that it was therefore necessary to examine not only individual incidents complained of but also the overall context and pattern within which such infractions transpired. ${ }^{99}$ As noted above, the lawyers in Kurdish cases were seeking to effectuate politico-legal change in Turkey and to challenge the denial of the Kurdish problem. Francoise Hampson, one of the chief representatives of the Kurdish applicants, reportedly said that their strategy proved effective in creating 'a significant number of court judgments [with the effect that] Turkey could no longer pretend in the Council of Europe that there was not a human rights problem. ${ }^{100}$ She regretted, however, that although findings of gross violations were important tools of the strategy to 'change things,' they were 'less successful' in convincing the Court 'to recognize the scale of the problem'. ${ }^{101}$ Indeed, while fact-finding hearings revealed a pattern of certain transgressions (such as house-burnings, disappearances, extrajudicial killings and a lack of remedies), the resulting findings were treated as isolated incidents — an approach which gives credence to the idea that the Convention system is not suited to dealing with gross or systemic violations. ${ }^{102}$

intensity and Turkey's ambition to join the EU had instigated legal reforms. The new Court's struggle to deal with the increasing backlog of cases and the expensive nature of the fact-finding missions had also contributed to this development. See Leach, n 92 above, p $41 \mathrm{ff}$.

${ }^{98}$ Before the recognition of the right of individual petition, the inter-State mechanism was invoked a few times to address the issue of systematic violations. See Cyprus $v$ Turkey, App No 8007/77, 13 D\&R 85

(1979); Cyprus v Turkey (1982) EHRR 482; France, Norway,Denmark, Sweden and The Netherlands v Turkey, App Nos 9940-44/82, 35 DR 143 and 44 DR 31 (1983).

${ }^{99}$ See Aisling Reidy et al, 'Gross Violations of Human Rights: Invoking the European Convention on Human Rights in the Case of Turkey’ (1997) 15 NQHR 161, 165.

${ }^{100}$ Interview with Françoise Hampson, Ankara, 9 March 2008, cited in Kurban et al, n 77 above, p 5.

${ }^{101}$ Ibid.

102 See Menno T. Kamminga, 'Is the Euopean Convention on Human Rights Sufficeintly Equipped to Cope with Gross and Systematic Violations,' (1994) 12 NQHR 153. 
The following cases attest to the gravity of the allegations concerning the existence of an administrative practice in Turkey. In Aksoy, the applicant complained that he was tortured during his 14-day incommunicado detention in the emergency region where national authorities tolerated widespread violations of human rights and failed to provide effective remedies. ${ }^{103}$ Although the Court found domestic remedies illusory and inadequate, thereby absolving the applicant from the rule of exhaustion, 'it did not find it necessary' to determine whether there indeed existed an official practice of systematically tolerating human rights abuses. ${ }^{104}$

Likewise, the applicants in Akdivar complained that they were victims of an administrative policy which condoned the destruction of some three thousand villages and the displacement of almost two million people. They further stressed that since massive population displacement was a State-inspired strategy, it was impossible to make recourse to effective remedies. ${ }^{105}$ Whilst the Court found exceptional circumstances which absolved the applicants from their duty to exhaust local remedies, it did not consider the evidence strong enough to justify a finding of an administrative practice. ${ }^{106}$

Analogously, in a string of judgments concerning the claim that the applicants had been subjected to gross violations on account of their Kurdish origin, the Strasbourg organs found allegations of ethnic discrimination to be unsubstantiated; this mirrors what occurred in relation to cases from Northern Ireland, where applicants were repeatedly told that they had not adduced enough evidence to substantiate their claims that they had been discriminated against on grounds of religion, political opinion, national origin or association with a national minority. Likewise, in $K u r t,{ }^{107}$ where the applicant asserted that forced disappearances mainly targeted people of Kurdish origin, the Court deemed the evidence insufficient to reach such a conclusion. Similarly, in both Akdivar and Hasan Ilhanli, ${ }^{108}$ the Court refused to draw an inference of a discriminatory policy of mass house demolitions targeting the Kurdish community. ${ }^{109}$

Put in a nutshell, submissions that violations were part and parcel of an administrative or discriminatory practice were dismissed by the Strasbourg bodies either on the basis of insufficient evidence or on the unsatisfactory ground that it was 'not necessary to determine

\footnotetext{
${ }^{103}$ Aksoy, n 81 above, paras 46-47.

${ }^{104}$ Ibid, paras 50-57.

105 Akdivar, n 65 above, para 60.

${ }^{106}$ Ibid, 88.

${ }^{107}$ Kurt, n 87 above, para 147.

${ }^{108}$ Akdivar, n 65 above; Hasan Ilhan v Turkey, App No 22494/93, judgment of 9 November 2004,

${ }^{109}$ Akdivar, ibid, para 99; Hasan Ilhan, ibid, para130.
} 
whether the failings identified [were] part of a practice adopted by the authorities. ${ }^{110}$ As with cases from Northern Ireland, the Convention organs steadfastly adopted a case-by-case, factspecific approach to all counter-terrorism related issues. While a finding that there had been a systematic administrative or discriminatory practice would have placed much heavier pressure on Turkish authorities to conduct its anti-terror measures in line with Convention requirements, Strasbourg's choice of handling each case as an isolated incident was arguably critical for ensuring that Turkey did not become wholly alienated from the Council of Europe. This quasipolitical stance might also have motivated the ECtHR when dealing with some of the human rights issues arising in Northern Ireland, in particular the alleged abuses resulting from derogation notices, discrimination on grounds of religious belief or political opinion, internment without trial and ill-treatment of detainees. $\mathrm{s}$

\section{Village destructions}

One of the most distinguishing features of the Turkish conflict has been the village destruction phenomenon. In its combat against the PKK insurgency, the Turkish security forces evacuated and destroyed over three thousand rural settlements. The practice of village destruction during the 1990s forced over three million inhabitants to leave their homes. ${ }^{111}$ Kurds who were suspected of providing shelter to the PKK, or who refused to be recruited into the State-sponsored paramilitary 'village guard system', were at times made an example of by having their villages burnt down - a strategy which was aimed at depriving the PKK of access to food, shelter and potential recruits. ${ }^{112}$ The motive behind the village destructions has never been the subject of Strasbourg scrutiny; the rulings eschewed the difficult question of whether destructions had been a form of punishment for the applicants' alleged involvement in the PKK. ${ }^{113}$

Instead the European Court has focused on whether, in individual cases, Articles 3 and 8 of the ECHR have been violated. In assessing whether home destructions resulting in massive uprooting of populations attained the minimum level of severity for the purposes of Article 3, the Court adopted a contextual approach by taking into account the physical and mental effects

\footnotetext{
${ }^{110}$ Mahmut Kaya v Turkey App No 22535/93, judgment of 28 March 2000, para 128.

111 The PKK, too, contributed to forced displacement of people, especially by targeting those who agreed to become 'village guards' to help fight the insurgency.

112 Since the capture of the PKK leader in 1999, the government has announced a number of programmes to encourage the return of the forcefully displaced people. Nevertheless, the programmes have failed due to notable deficits in planning and financing the resettlement.

${ }^{113}$ Ayder v Turkey (2004) App No 23656/94, judgment of 8 January 2004, paras 110-115; Yöyler v Turkey

(2003) App No 26973/95, judgment of 24 July 2003, para 74.
} 
of the treatment. In Dulas, ${ }^{114}$ the fact that the applicant was over 70 when her home and property were destroyed before her eyes, leaving her destitute and without shelter and obliging her to leave her accustomed community, and the fact that there was no official remedy to alleviate her plight, were all considered in reaching the conclusion that the complained acts amounted to inhuman treatment. ${ }^{115}$ Again, in Yoyler, ${ }^{116}$ the destruction of the applicant's home was not only found to constitute a grave and unjustified interference with the applicant's rights to privacy and property, but also with his right to freedom from inhuman or degrading treatment. The finding of inhuman treatment was similarly justified on grounds that the victim's house was burned before the eyes of his family members, rendering them vulnerable without any support and obliging them to seek a livelihood elsewhere. ${ }^{117}$ In a series of cases brought on behalf of the displaced, the Strasbourg bodies generally found the authorities responsible for destroying homes and possessions. ${ }^{118}$ The Court acted on the premise that since home and privacy are inextricably connected, the destruction of the villages constituted grave and unjustified interferences with the applicants' rights to privacy and family lives as well as the peaceful enjoyment of their possessions. ${ }^{119}$

Although the Court recognised the extent of the village destruction problem and the lack of accountability for the perpetrators, it has never contextualised the events within a broader framework. Apart from requiring the payment of compensation to the victims, this approach did not provide a compelling incentive to the government to identify and punish those responsible for the atrocities. Significantly, however, in a judgment delivered in $2013,{ }^{120}$ the Court did require Turkey (under the supervision of the Committee of Ministers) to identify and punish the perpetrators of an indiscriminate bombing of two villages in 1994, which caused 38 deaths and numerous injuries. These belated steps are of crucial importance for public acknowledgement of past wrongs and for eradicating impunity for serious human rights violations.

\section{Enforced disappearances and the right to life}

\footnotetext{
${ }^{114}$ Dulas v Turkey App No 25801/94, judgment of 30 January 2001.

115 Ibid, paras 53-55

116 Yöyler, n 113 above.

${ }^{117}$ Ibid, paras 71-76; also see, Selcuk and Asker, n 68 above, paras 77-78.

${ }_{118}$ Menteş n 68 above; Akdivar, n 65 above.

119 Selcuk and Asker, n 68 above, paras 83-87.

${ }^{120}$ Benzer v Turkey App No 23502/06, judgment of 12 November 2013.
} 
Following his official visit to Turkey in November 2012, Christof Heyns, the UN Special Rapporteur on Extrajudicial, Summary or Arbitrary Executions, observed that one of the most urgent challenges facing Turkey was to eradicate the culture of impunity for those responsible for unresolved killings and deaths in custody, in particular during the 1990s. The Rapporteur expressed his regrets that only a negligible number of trials had been conducted, as there had been a lack of political will to hold perpetrators of gross violations accountable before the statute of limitations expired. ${ }^{121}$

In cases of alleged disappearances and extrajudicial killings, the Court considered allegations of Article 2 violations in both their substantive and procedural aspects. Regarding substantive claims, the Court generally applied a high standard of proof by requiring allegations that disappearances and killings had been committed by the security forces to be proved beyond reasonable doubt. In this class of case, the Court did not initially give much weight to the wider context, nor did it give due acknowledgement to the extreme difficulty facing the applicants in obtaining hard evidence from non-cooperative authorities. When applicants had no conclusive evidence but relied on mere inferences or unproven hypotheses, the Court did not consider reversing the burden of proof - even when the government was condemned for a lack of effective investigations. ${ }^{122}$ It should be noted, however, that when the Court deemed the evidence inadequate for it to conclude beyond reasonable doubt that the disappeared person had been killed by State agents, it then turned to the question whether there had been an effective investigation of the incident. When the Court held that the national authorities failed to carry out adequate investigations into the circumstances surrounding the matter, it generally found a procedural violation of Article 2. ${ }^{123}$ There are similarities here with the cases coming to Strasbourg from Northern Ireland: the United Kingdom government has never been condemned by the ECmHR or ECtHR for breaching its negative obligation not to deprive people of their lives, but it has been condemned for not properly investigating controversial killings in which it may in some way have been implicated.

Kurt $v$ Turkey, ${ }^{124}$ decided in 1998, was the first involuntary disappearance case. The applicant submitted that her son might have died in unacknowledged police custody, within a

\footnotetext{
${ }^{121}$ Christof Heyns, 'Report of the Special Rapporteur on Extrajudicial, Summary or Arbitrary Executions,' Human Rights Council, 29 ${ }^{\text {th }}$ Session, A/HRC/29/37/Add 4.

122 Judge Bonello criticised this approach by noting that the finding of a substantive violation should not rest on the applicant's capacity to produce evidence in cases where the State wrongfully obstructs access to relevant evidence: Tahsin Acar v Turkey (2004) 38 EHRR 2, Concurring Separate Opinion of Judge Bonello, paras 5-12. ${ }^{123}$ See, among others, Cakiçi, n 94, paras. 85-87; Tahsin Acar v Turkey, ibid, para 234; Buldan v Turkey, App No 28298/95, judgment of 20 April 2004, para 90; Nuray Şen v Turkey (No 2) App No 25354/94, judgment of 30 March 2004, para 179.

${ }^{124}$ Kurt, n 87 above.
} 
political context characterised by high incidents of torture, unexplained deaths and forced disappearances. Having applied its high standard of proof, the Court found no substantial breach of Article 2 on grounds that the allegations were merely presumptions resting on purportedly tolerated practices of disappearances and extra-judicial killings of detainees. ${ }^{125}$ Concerning the claim that the failure to conduct an effective investigation into the disappearance constituted a separate violation of Article 2, the Court surprisingly examined the claim under Article 5, ruling that the victim was subjected to unacknowledged detention in the complete absence of the safeguards contained in Article 5. ${ }^{126}$

The case of $\mathrm{Cakici}^{127}$ occasioned for the first time a finding of a substantial breach of Article 2. The applicant complained that his brother disappeared in 1993 after being subjected to unacknowledged detention by the security forces. In 1996, only after the transmission of government submissions to the Commission, the applicant learned that his brother had been killed by the security forces in an alleged clash with PKK militants in 1995. The government asserted that the victim was identified by his identity card found on his person. Deviating from its approach in Kurt, the Court not merely examined the disappearance claim under Article 2 but attached significant weight to 'circumstantial evidence based on concrete elements' in reaching the conclusion that the applicant must have died after his unacknowledged detention. ${ }^{128}$ While the facts of Cakici were not markedly distinct from those of Kurt, the Court in the instant case had no hesitation in drawing 'very strong inferences' from the authorities' claim that the victim's identity card was found on the body of a dead terrorist. ${ }^{129}$

In another leading case, Timurtas $v$ Turkey, ${ }^{130}$ where the victim lost his life during his six-and-a-half year unacknowledged detention, the Court found a violation of Article 2 on both substantial and procedural grounds. ${ }^{131}$ Once again, in a bid to distinguish its approach from Kurt, the Court employed rather unconvincing reasoning by stating that in the present case the passage of time since the detention was six-and-a-half years (two years longer than in Kurt), that it had been established that the victim was taken to a place of detention (in Kurt the victim was seen to be surrounded by the soldiers), and that there was no doubt that the victim was wanted by the authorities about his alleged involvement with the PKK (in Kurt the victim was

\footnotetext{
125 Ibid, para 108 .

${ }^{126}$ Ibid, paras 128-129.

127 Cakiçi, n 94 above.

128 Ibid.

129 Ibid.

${ }^{130}$ Timurtas $v$ Turkey (2001) 33 EHRR 6.

${ }^{131}$ Ibid, paras 81-90. For a similar conclusion reached by the Court, see, Orhan n 89 above.
} 
merely under suspicion of having links with that organisation). ${ }^{132}$ Despite the relative insignificance of these differences, ${ }^{133}$ the positive shift in the ECtHR's position clearly indicated that it tacitly acknowledged the wider socio-political context of the 1990s within which unacknowledged detentions and enforced disappearances had posed serious threats to human life.

\section{The right not to be ill-treated}

Apart from the findings of ill-treatment in village destruction cases, Strasbourg bodies have also identified incidents of torture committed by the security agents. In the Turkish cases the Court continued to require a higher level of egregiousness of ill-treatment as a central parameter of torture, which is singled out as carrying a special stigma. Aksoy ${ }^{134}$ was the first individual case to result in a finding of torture. In this case, the applicant complained that he was forced to strip naked and was then suspended for long periods by the arms tied behind his back - a form of ill-treatment known as 'Palestinian hanging.' The Court concluded that such treatment, considering its serious and cruel nature, could only be described as torture. ${ }^{135}$ It is worth noting that Aksoy also occasioned a significant shift in the distribution of the burden of proof in some allegations of torture: if individuals are taken into custody in good health but are found on release to be injured, national authorities must offer a plausible explanation for the injury. ${ }^{136}$

Since acts of torture are often committed with the intention of obtaining information, inflicting punishment or intimidating a suspect, the Court in Dikme ${ }^{137}$ made reference to the concept of 'purpose' as an element of torture. Having referred to the definition of torture in the 1987 UN Convention against Torture, the Court determined that the infliction of ill-treatment 'was intentionally meted out to the ... applicant by agents of the State in the performance of their duties, with the aim of extracting a confession or information about the offences of which [the detainee] was suspected'. ${ }^{138}$ However, the Court did not further clarify whether the

\footnotetext{
132 Timurtas, ibid, para 85.

${ }^{133}$ In his dissenting opinion, Judge Gölcüklü rejected the idea that substantial factual differences in the present case could justify a departure from the precedent set in Kurt. He noted that the above-mentioned arguments put forward by the majority to distinguish the instant case were simply 'artificial and superficial, assertions unsupported by fact, a sort of trompe-l'œil.' Ibid, Partly Dissenting Opinion of Judge Gölcüklü, para 4.

${ }^{134}$ Aksoy, n 81 above.

135 Ibid, para 64.

136 Ibid, para 61.

${ }^{137}$ Dikme v Turkey App No 20869/92, judgment of 11 July 2000.

138 Ibid, para 95.
} 
purposive element constituted an 'essential ingredient' of torture. Again in Akkoc, ${ }^{139}$ where the victim was subjected to various forms of ill-treatment including sexual abuse, electric shocks, cold water treatment and threats to her children, the Court found that the severity of the purposeful infliction of ill-treatment had met the higher threshold of torture. ${ }^{140}$ Notwithstanding such unelaborated references to the notion of purpose, it appears that the 'severity' test still remains the ultimate yardstick whereby the Court distinguishes torture from ill-treatment.

Although most findings of torture concerned an accumulation of cruel and inhuman acts, in the ground-breaking case of Aydin v Turkey ${ }^{141}$ the Court unprecedentedly recognised that an act of rape, in and of itself, could amount to torture. In Aydin, the applicant was repeatedly beaten, forced to remain naked, and then raped by an unidentified agent in police custody. ${ }^{142}$ The Court held that 'the accumulation of acts of physical and mental violence inflicted on the applicant and the especially cruel act of rape to which she was subjected amounted to torture'. ${ }^{143}$ Significantly, the findings of Aydin inspired a landmark judgement in Akayesu $^{144}$ where the International Criminal Tribunal for Rwanda found responsibility for genocide and war crimes based on acts of rape.

When the lack of adequate and effective local remedies for torture victims became the subject of complaints, the ECtHR emphasised the fact that terrorism did not give authorities carte blanche to hold suspects in detention free from judicial review and to deny unlawfully detained individuals the right to seek effective remedies. ${ }^{145}$ Likewise, the Court found breaches of the right to an effective remedy on account of the failure of national authorities to carry out prompt and effective investigations into alleged violations capable of leading to the identification and punishment of those responsible and to the compensation of the victim where necessary. ${ }^{146}$ These judgments, despite their non-assertive character, sought to break the cycle of impunity for perpetrators of gross violations. In this connection, when the perpetrators of torture in $\mathrm{Bati}^{147}$ could not be prosecuted before the statutory limitation period had expired, the Court vehemently noted that, due to the lack of sufficient promptness and reasonable diligence

\footnotetext{
${ }^{139}$ Akkoc v Turkey (2002) 34 EHRR 51.

${ }^{140}$ Ibid, para 115.

${ }^{141}$ Aydin $\mathrm{n} 91$ above.

142 Ibid, para 80.

143 Ibid, para 86.

${ }^{144}$ International Criminal Tribunal for Rwanda, The Prosecutor v Jean-Paul Akayesu, ICTR-96-4-T, Trial

Chamber 1, 2 September 1998.

${ }^{145}$ Sakik v Turkey (1998) 26 EHRR 662, paras 44-58.

${ }^{146}$ See, Aydin, n 91 above, paras 103-109; Dikme, n 137 above, paras 98-104.

${ }^{147}$ Bati v Turkey (2006) 42 EHRR 37.
} 
on the part of national authorities, 'the main perpetrators of acts of violence have enjoyed virtual impunity, despite the existence of incontrovertible evidence against them' ${ }^{148}$

\section{The impact of Strasbourg case law on Turkish law and practice}

As in the case of Northern Ireland, it is possible to draw links between some of the conclusions reached by the ECtHR in applications lodged against Turkey and subsequent specific reforms to Turkish domestic law and practice. Starting in 1999, when Turkey was first officially recognized as an EU candidate, and until recent times, Turkey has adopted various crucial measures to improve its tarnished human rights record and thereby qualify for full EU accession negotiations. The reforms were introduced in order to meet the socalled Copenhagen criteria, but several actually derived from Court judgments issued in Strasbourg. ${ }^{149}$ The reforms included critical amendments to the Constitution such as the elimination of military judges from the State Security Courts (SSCs), ${ }^{150}$ the erosion of military dominance at the National Security Council ${ }^{151}$ and the granting of supremacy to international human rights treaties over national law, ${ }^{152}$ the last being a development which secured the direct application of Strasbourg judgments within Turkey's domestic legal system. A further effort to reduce the number of applications lodged at the ECtHR came with the amendment to Article 148 of the Constitution, which enabled individuals to submit complaints to the Turkish Constitutional Court before having to resort to the ECtHR. ${ }^{153}$

In response to an ECtHR pilot judgment, ${ }^{154}$ Turkey also set up a Compensation Commission with a view to providing satisfactory redress for those who suffered from excessive delays in judicial proceedings. This remedy enabled the ECtHR to redirect more than 2,500 pending applications back to national courts. ${ }^{155}$ The Compensation Commission complemented an earlier remedial action which sought to ensure adequate reparations for

\footnotetext{
148 Ibid, para 147.

149 These criteria were first established at the Copenhagen European Council in 1993; they are since reflected, as amended, in Article 49 of the Treaty on European Union. For negotiations to get started the candidate country must satisfy at least the first criterion, which is that it enjoys stability of institutions guaranteeing democracy, the rule of law, human rights and respect for and protection of minorities.

${ }^{150}$ SSCs were set up under the 1982 Turkish Constitution to deal with offences against national security. In the precedent-setting case of Incal v Turkey (1998) 29 EHRR 449, the ECtHR found a violation of Article 6 in view of the presence of a military judge among the members of the SSC.

${ }^{151}$ Law No 4963, 30 July 2003.

${ }^{152}$ Law No 5170, 7 May 2004.

${ }^{153}$ Law No 5982, 13 May 2010. Celebrating this reform, the ECtHR based its inadmissibility decision in $U z u n$ on the notion that domestic remedies had not been exhausted: Uzun v Turkey App No 10755/13, decision of 30 April 2013, paras 68-71.

${ }^{154}$ Ümmühan Kaplan v Turkey App No 24240/07, pilot judgment of 20 March 2012.

${ }^{155}$ ECtHR Annual Report 2013, Registry of the European Court of Human Rights Strasbourg, 2014, p 8.
} 
victims of human rights abuses committed in pursuit of anti-terrorism. ${ }^{156}$ Amelioration of the procedural safeguards at police custody is worth mentioning too. Deferring to the Salduz judgment, ${ }^{157}$ Turkey adopted a series of measures to remove barriers which inhibited early access to legal assistance for those on remand and other untried detainees. ${ }^{158}$

Further democratic reforms encompassed the abolition of the death penalty ${ }^{159}$ the introduction of a zero tolerance policy on torture ${ }^{160}$ (which reduced significantly the number of reported cases of torture and ill-treatment), as well as the lifting of the decades-old state of emergency regime ${ }^{161}$ and restrictions on Kurdish broadcasting. Although restrictions remained on the use of the Kurdish language in public education, ${ }^{162}$ these progressive cultural initiatives, culminating in the formation of a State-run Kurdish TV channel, marked a dramatic departure from the assimilationist policies of the past. ${ }^{163}$

Regrettably, since the second half of 2015 the pace of reforms has come to a standstill. Even before the recommencement of hostilities, change in practice was generally slow and faltering, for the administrative and juridical structures often resisted reforms, in large measure due to their statist reflexes which urged them to maintain the political status quo. ${ }^{164}$ The high number of cases against Turkey at Strasbourg also demonstrates that there is not yet an adequate incorporation of European jurisprudence into the country's practices. ${ }^{165}$ Turkey continues to rank among the countries that have the highest number of non-implemented

\footnotetext{
${ }^{156}$ See, The Law on the Compensation of Damages that Occurred due to Terror and the Fight against Terror, Law No: 5233, 17 July 2004, published in the Official Gazette on 27 July 2004.

157 Salduz v Turkey (2009) 49 EHRR 19. In this case the Grand Chamber ruled that all persons held in custody under the age of 18 should be given access to legal advice before being questioned by the police.

${ }^{158}$ After the Salduz case (ibid) had been lodged with the ECtHR in 2002, Turkey adopted Law No 4928 on 15 July 2003 to lift restictions on access to legal assistance for cases tried before the SSCs. Also, a new Code of Criminal Procedure entered into force on 1 June 2005; this expanded the scope of the right to access to legal assistance for those on remand.

${ }^{159}$ Law No 5218, 14 July 2004.

160 Act No 5271, 4 December 2004.

161 The emergency regime had expired when it was not renewed on 30 November 2002.

${ }^{162}$ Article 42 of the Constitution prohibits the education of children in their non-Turkish mother tongues.

${ }^{163}$ In 1991, the then president, Suleyman Demirel, for the first time spoke of a 'Kurdish reality' in the Turkish

Republic. Prior to this, Kurds were argued to be Turks who had changed their language. In 1936, the Governor of Tunceli (Dersim) maintained that Kurds were none other than 'mountain Turks'. See further, Kemal Kirisci and Gareth M Winrow, The Kurdish Question and Turkey: An Example of Trans-State Ethnic Conflict (Frank Cass \& Co Ltd, London, 1997) pp 102-103.

${ }^{164}$ It is usually argued that the bureaucratic and judicial elites in Turkey often see it as their mission to preserve the legacy of the centralised political system to the detriment of the interests of non-majority cultural groups. See Ergun Ozbudun and Fusun Turkmen, 'Impact of the ECtHR Rulings on Turkey's Democratization: An Evaluation,' (2013) 35 Human Rights Quarterly 985, 1002.

165 At the end of 2015 some $13 \%$ of the applications pending at the ECtHR were against Turkey $(8,450$ out of 64,850): ECtHR, Analysis of Statistics 2015, p 8, available at http://www.echr.coe.int/Documents/Stats_analysis_2015_ENG.pdf, last accessed 22 April 2016.
} 
ECtHR judgments because of structural problems that hinder the effective protection and promotion of human rights. ${ }^{166}$

As the EU's 2015 Report underlined, the recent re-escalation of the conflict between the military and PKK insurgents has led to tangible backsliding in some key areas, including freedom of expression, judicial independence and, perhaps most importantly, the process for settling the Kurdish issue. ${ }^{167}$ Another 2015 Council of Europe Report stressed that Turkey should make progress in such matters as re-opening unfair criminal proceedings, reducing the length of detention on remand and preventing excessive actions of the security forces. ${ }^{168}$ What is more, securing the criminal liability of public officials for grave breaches remains problematic. Despite numerous Strasbourg rulings requiring Turkey to conduct effective investigations into alleged violations, with a view to the potential prosecution of suspected offenders, Turkey has yet to eradicate the culture of impunity for violations committed within the context of counter-terrorism. Among the major obstacles to accountability are the need to obtain administrative authorisation to initiate proceedings against the security personnel and the 20-year statute of limitations for the prosecution of those responsible for egregious breaches. ${ }^{169}$ The result is that many unresolved offences from the 1990s now risk being timed out, forgotten and unaccounted for.

\section{Conclusion}

After such a brief analysis of the Convention jurisprudence arising out of the conflicts in Northern Ireland and Turkey it would be unwise to try to identify specific juridical patterns established by the Convention organs or to draw all-encompassing lessons as to how the jurisprudence could be employed to balance security concerns and human rights issues in other conflict zones. It nevertheless appears plausible to offer the following two broad observations on the Northern Irish and Turkish experiences.

First, significant difficulties remain with the breadth of the margin of appreciation afforded to States regarding their right to declare a public emergency and to derogate from

\footnotetext{
${ }^{166}$ Committee on Legal Affairs and Human Rights, 'Implementation of Judgements of the European Court of Human Rights: $8^{\text {th }}$ Report, 23 July 2015, p 3.

${ }^{167}$ European Commission, 'Commission Staff Working Document: Turkey 2015 Report', 10 November 2015. 168 Parliamentary Assembly, 'Implementation of Judgments of the European Court of Human Rights', Doc 13864, 9 September 2015, p 27ff.

${ }^{169}$ See the Law on the Prosecutions of Public Officals and other Public Employees, Law No 4483, 2 December 1999; Turkish Criminal Code (Act No. 765), 1 March 1926; New Turkish Criminal Code (No 5237), 26 September 2004.
} 
the ECHR. Granting States such a wide discretion has left the ECtHR in a rather weak position when exercising its supervisory functions at times of conflict. It is certainly the case that in relation to both of the conflicts examined here the Court has struggled to pinpoint and condemn various systematic practices amounting to gross violations of human rights. Difficulties associated with fact-finding, with the standard and burden of proof, and with external political factors have combined to neuter the effectiveness of the Court in putting a break on unacceptable large-scale abuses. It might have been possible for these abuses to have been considered in more detail through strategically lodged inter-State applications, but these have been few and far between. As regards applications from individuals, some of the Convention's stringent admissibility criteria have hindered a number of potentially meritorious applications from being considered by the Strasbourg organs during times of internal conflict, and in situations where admissibility hurdles have been overcome further obstacles have been placed in the applicants' path in terms of deference to state discretion and lack of commitment to a truly 'dynamic and evolutive' and 'practical and effective' approach. In short, in this context the ECHR has not been treated as a 'living instrument' to the degree that it might have been. ${ }^{170}$

Second, it is principally in conflict-related cases that the Court has, to its credit, developed the doctrine of substantive positive obligations arising out of Articles 2 and 3 of the ECHR. By finding violations of these positive obligations, sometimes described as procedural rather than substantive, the Court has managed to send a message to the States concerned that their discretion is not as broad when they are asked by litigants to get to the bottom of what practices were carried out with or without the State's blessing. On the other hand, Articles 13 and 14 of the Convention, guaranteeing the rights to an effective remedy and to be free from discrimination, have been relatively under-utilised by the Court when processing complaints in the context of internal conflicts. This is disappointing, since it represents a neglected opportunity to make a helpful contribution to the settlement of conflicts centred around contested ethno-political, racial, linguistic and religious differences. This might be an area where, through reports and interventions, the Council of Europe's Commissioner for Human Rights could play a more prominent role in helping the

\footnotetext{
${ }^{170}$ For the 'dynamic and evolutive', 'practical and effective' and 'living instrument' approaches see e.g. D Harris et al, Harris, O'Boyle and Warbrick Law of the European Convention on Human Rights $\left(3^{\text {rd }}\right.$ edn, 2014) 8-10 and 18; Ed Bates, The Evolution of the European Convention on Human Rights (2010) 320-3.
} 
Court to address in a more meaningful way the range of allegations of systematic and gross violations which are often at play within conflicted societies. 